\title{
Natural Disasters and Agrarian Conflict
}

\author{
Adha Fathiah $^{1}$, Afrizal $^{2}$, Jendrius $^{3}$ \\ \{fathiah.adha@gmail.com ${ }^{1}$, afrizal_2002au@yahoo.com², jendrius@yahoo.com ${ }^{3}$ \} \\ Department of Sociology, University of Andalas, Padang, Indonesia
}

\begin{abstract}
The tsunami disaster that stroked Aceh in 2004 not only resulted in massive casualties and huge economic losses, has also resulted in massive horizontal agrarian conflicts. This article will discuss how natural disasters cause horizontal agrarian conflicts. The question that will be answered is how the tsunami caused the agrarian conflicts among the people? How such agrarian conflicts affect the reconstruction effort of after tsunami which is a series of disaster mitigation. This article uses a literature review consisting of research reports, scientific journal articles, and media reports on the impact of the 2004 Aceh tsunami. Study results and media reports suggest that the tsunami disaster resulted in the loss of boundaries of community-controlled land and this causes land disputes among neighbors that influences reconstruction efforts undertaken by governments and NGOs. However, local wisdom on conflict mitigation contributes to the settlement of land conflicts and this has contributed to post-tsunami reconstruction efforts in Aceh. With that this article contributes to the development of knowledge on disaster mitigation.
\end{abstract}

Keywords: natural disasters, agrarian conflicts

\section{Introduction}

The tsunami disaster that struck Aceh in 2004 not only caused massive casualties and huge economic losses, the natural disaster has resulted in massive horizontal agrarian conflicts. The tsunami disaster resulted in a shift in the joints of social, economic, and cultural life of the community. In addition to claiming 167,000 lives; 130,000 people died and 37,000 missing [1], the tsunami left deep wounds and sorrow for abandoned victims, the earthquake and tsunami also destroyed infrastructure and various buildings, especially housing residents. The tsunami has caused a massive incident of agrarian conflict between citizens.

This paper shows how the tsunami caused the occurrence of an agrarian conflict. The question that will be answered is how the tsunami caused the agrarian conflict among the people? How such agrarian conflicts affect the reconstruction effort is a series of disaster mitigation. This article uses a literature review consisting of research reports, scientific journal articles, and media reports on the impact of the 2004 Aceh tsunami. Study results and media reports suggest that the tsunami disaster resulted in the loss of boundaries of communitycontrolled land. This issue influences reconstruction efforts undertaken by governments and NGOs. However, local wisdom in relation to the natural conflict mitigation community contributes to the settlement of land conflicts and this has contributed to post-tsunami reconstruction efforts in Aceh. This article contributes to the development of knowledge on disaster mitigation. 


\section{Literature Review}

\subsection{Impact of Aceh Tsunami Disaster}

The tsunami disaster had a major impact on the people of Aceh. The tsunami disaster caused various problems for the people and affected the smoothness of the rehabilitation and reconstruction process as an effort to recover the tsunami impact. The areas affected by the tsunami left almost no traces, including the infrastructure that was also destroyed. Table 1.1. The following shows the total amount of infrastructure collapse in Aceh due to the tsunami disaster, including:

Table 1. Infrastructure Losses in Aceh's Impacting Territory.

\begin{tabular}{cll}
\hline No & \multicolumn{1}{c}{ Jenis Kerugian } & \multicolumn{1}{c}{ Jumlah Kerugian } \\
\hline 1 & Usaha UMKM & 104.500 unit \\
2 & Perumahan & 139.195 unit \\
3 & Lahan Pertanian & 73.869 ha \\
4 & Tenaga Guru & 1.927 orang \\
5 & Perahu Nelayan & 13.828 unit \\
6 & Kerusakan Jalanan & $2.618 \mathrm{~km}$ \\
7 & Sekolah & 3.415 unit \\
8 & Fasilitas Kesehatan & 517 unit \\
9 & Gedung Pemerintahan & 669 unit \\
10 & Jembatan & 119 unit \\
11 & Pelabuhan Rusak & 22 unit \\
12 & Landasan Udara & 8 unit \\
\hline
\end{tabular}

Source: Recovery Platform, BRR Breakthrough

From the following table it can be seen that considerable losses occur in the housing population with the total number of houses destroyed reached 139,195 units. So that resulted in densely populated areas turned into a blank expanse and no longer found land boundaries due to the tsunami disaster that hit.

\subsection{Horizontal Agrarian Conflict}

Speaking of land conflicts, it would be better to know the definition of the conflict itself first. Conflict is the pursuit of conflicting goals from different groups. It shows a wider range of time and wider class struggles than armed conflict, with it being followed by means of peace or by using force. And a deep conflict involving human needs and can only be solved by eliminating the hidden causes [2].

Land conflicts with respect to the interaction process between two or more persons or groups each fighting for their interests or the same object, ie land and other objects related to the land such as water, plants, mines and also air in the boundary of land concerned [3]. Then In general there are several kinds of problematic nature of a land conflict, among others: 1) problems concerning priorities can be established as the holder of legal rights over land with rights or rights to land that have no rights, 2) denial of any reason for the right or evidence (3) conflicts or misstatements caused by improper or incorrect regulation, and 4) conflicts or other issues containing social aspects [4]. 
It is interesting to note that the land problems occurring as a result of the tsunami disaster in Banda Aceh not only cover the four general characteristics of the above mentioned soil problems, other land issues have occurred, namely the loss of the land boundaries of the population due to the tsunami and the clearing of the land using tools - heavy equipment, not only the evidence or supporting documents also perish. The result is that the process of settlement is difficult given the absence of benchmarks or marks of land boundaries and documents that can prove.

In the National Land Agency, the tsunami resulted in $10 \%$ of lost soil books and $90 \%$ of land titles in critical condition (wet, muddy with seawater) and $80 \%$ missing ground documents including maps cadastral ground. Furthermore, there are about 300,000 parcels of land affected by 170,000 parcels of urban land and 130,000 parcels of rural land. Damage to buildings and office facilities BPN Aceh and Banda Aceh and the loss of 30-40\% of BPN government employees resulted in land problems when the disaster becomes difficult to resolve quickly and accurately [5].

After the tsunami disaster and in times of emergency, people visit their homes to recognize the condition of their homes and land and to look for what is left and can be taken. They witnessed the house building is gone and the boundaries of the soil have been lost because the plots along the coast have been completely or spatially submerged by sea water. "Many plots of land along the coast are marked with trees or trails, but after wiping this wave of markers is lost" [6]. They then tried to identify the land again. This is the beginning of the dispute between citizens [7]. Citizens mutual claim rights to land. False statements about land ownership by some irresponsible persons [7].

Clashes between citizens of mutual land claims affect the reconstruction effort providing homes for homeless people. An NGO undertaking the Aceh reconstruction effort stated:

As of November 2006, 48,000 houses have been built in the province, but much remains to be done to reach the target of 128,000 homes. Two years after the tsunami, rebuilding destroyed homes and finding housing solutions for landless citizens are two of the most important tasks facing Aceh. The issue of land rights - the question of who owns the land - should be resolved if the people of Aceh will be rebuilt on a solid foundation. Without clear land rights, people who are rebuilding houses are at risk of a third party coming and claiming ownership of the land [6]

- According to Oxfam, reconstruction of houses for Acehnese affected by the tsunami can be done if "Survivors can clearly legalize land and property rights to minimize disputes and provide a strong social and legal basis for the rebuilding of Acehnese society". However, the settlement of land conflicts that have occurred is difficult because of several things [6].

- Lack of benchmarks or landmarks and documents that can prove.

- Most, if not all, of the affected packages do not have their border coordinates in the WGS84 system. The process of boundary relocation using technology is therefore difficult or impossible.

- Many cadastral survey monuments were destroyed or lost by the earthquake and tsunami. This complicates the reconstruction of boundaries in areas whose coordinates are directly or indirectly linked to this survey monument. 


\section{Research methods}

This article is compiled by using literature review method, with the aim to understand a phenomenon that has occurred by using available data that is by obtaining data and information consisting of research reports, articles in journals, and media reports on the impact of the tsunami Aceh in 2004. Literature review was conducted to obtain information and data by finding as many references as possible in order to produce good writing without having to conduct interviews in the field.

\section{Research Results and Discussion}

\subsection{Land Dispute Settlement}

Agrarian conflict can be solved in two ways, litigation and non-litigation. Litigation is defined as the settlement path through the judiciary, while non-litigation is a settlement of disputes outside the judiciary. Afrizal conveys how the community succeeded in using nonlitigation channels to resolve their agrarian dispute with a company. According to Afrizal, the presence of competent third parties, knowing ways to resolve conflicts outside the judiciary, and the absence of state legal barriers are two important factors leading to the success of conflict resolution outside the judiciary [8].

According to the Oxfam study [6] only about 25 percent of the land in the tsunami-affected area is private land, another 75 percent of adat land. The following will discuss how local adat institutions are able to resolve post-tsunami land conflicts whose boundaries have been lost and key witnesses have died from the tsunami.

\subsection{The role of Gampong}

In Aceh, horizontal agrarian conflicts of peace or post-tsunami land issues have been largely resolved in gampong, and not in court. Many residents choose to take this path due to various reasons. One of the reasons residents to use the settlement of land conflicts in the gampong is the cost that is affordable and not protracted. Village Head (Keuchik) plays an important role. Important actors in the gampong involved are none other than gampong officials consisting of Keuchik, tuha peut, tengku imum, and community leaders.

\subsection{Indigenous Deliberation}

Salim mentioned that the process of settling the land dispute after the tsunami was conducted by Keuchik by holding deliberations based on local customs. Local customs in question is to prioritize deliberation and compromise among the parties who are at loggerheads and assisted by living witnesses to give testimony. The final outcome of the joint deliberations is agreements that have been agreed by the conflicting parties [9].

However, the actual implementation of land settlement according to adat can be found in the formal law of land, namely article 18 paragraph (1) Government Regulation number 24 of 1997 regarding land registration states: "Determination of land parcels already owned by a right that has not been registered or which has been registered but there is no measurement / picture of the situation or the existing situa- tions / pictures are no longer appropriate to the actual circumstances, the adjudication committee in the systematic land registration or by the head of the land office in sporadic land registration, based on border appointment by holder of the adjacent land rights. "Further Article 19 paragraph (1) of PP 24/1997 states:" If in the 
determination of the boundary of the parcel as referred to in Article 18 paragraph (1) there is no agreement between the holder of the adjacent land rights, the land is strived for temporarily done base bounds that are in reality the boundaries of the parcels of land concerned [9].

Similarly, the settlement of land issues that are carried out through the outer court in the gampong is by deliberations conducted by gampong devices with the aim of reaching agreement on the problems of land boundaries. The form of solving this soil problem is called CDA (Community Driven Adjudication) or it can be said to be a community based land registration process [9].

The location of deliberations on post-tsunami land issues is not always done in buildings, meunasah, residents or gampong offices, but more often in the field, especially where the lands whose boundaries are to be determined. Deliberation is done many times and takes up to several months for a gampong. This is because solving the land problem can not be solved only one by one, but also involves all the landowners, or their heirs, located adjacent to the boundary of the land (Salim in Research Report of International Development Law Organization, 2006: 8-9)

When the process of measuring the boundaries of parcels of land in the field, the landowner or his heirs, is present together with the owners of adjacent parcels, the head of the local hamlet, tuha peut and keuchik to ensure the markers of land boundary. If no agreement is obtained between the owner of the parcels concerned regarding landmark marks, the boundary of the parcel shall be measured and declared a temporary limit. In the event that an owner of the land, or his heirs, is unable to attend or is no longer known to exist, the marker of the land boundary shall be determined on the basis of the knowledge of the gampong stakeholders present at the time and the boundary of the plot shall be declared a temporary limit [9].

\section{Conclusions and Recommendations}

Tsunami disaster has caused many problems perceived by every citizen in the affected location. One such problem is the loss of land boundaries as it was swept away by the tsunami disaster. It does not stop there, the problem of the loss of land boundaries becomes the basis of the emergence of disputes between citizens who claim the boundaries of their respective land.

The settlement is pursued to result in an agreement among conflicting citizens by conducting non-litigation channels. It means that the conflicting citizens choose to take the deliberation path in gampong initiated by the gampong officials such as Keuchik, Tuha Peut, Teungku Imum. In addition to the path chosen to be the determinant of the successful settlement of land disputes, the role of third parties is also a key success for reaching agreement among the conflicting citizens.

Land disputes or land issues that can be settled through out-of-court channels are very short of government attention marked by the absence of official records to serve as documents that may be useful later on for individuals, communities and governments alike.

Then to be understood is the existence of good communication and cooperation built between the government, NGOs, and society for the future can achieve success in post-disaster repair efforts.

\section{References}

[1] BRR (Aceh and Nias Reconstruction Board), 2006. Aceh and Nias Two Years After the Tsunami.R. Nicole, "Title of paper with only first word capitalized," J. Name Stand. Abbrev., in press. 
[2] Miall, Hugh., Ramsbotham, Oliver.,Woodhouse, Tom. 2011. Resolusi Damai Konflik Kontemporer. Jakarta: Raja Grafindo Persada.

[3] Afrizal. 2006. Sosiologi Konflik Agraria Protes-protes Agraria dalam Masyarakat Indonesia Kontemporer. Andalas University Press Padang.

[4] Santoso, Urip. 2005. Hukum Agraria dan Hak-hak atas Tanah. Jakarta: Prenada Media.

[5] Benny, I, et. al. 2006. Post-Tsunami Land Parcel Reconstruction in Aceh: Aspects, Status and Problems.

[6] Laporan Briefing Oxfam, 2006. Hak Atas Tanah di Aceh Setelah Dua Tahun Tsunami.

[7] Katahati Institute. 2009. Permasalahan Sertifikasi Tanah Hak Milik Masyarakat Pascatsunami dan Potensi Sengketa Agraria.

[8] Afrizal. 2015. Third Party Intervention in Terminating Oil Palm Plantation Conflicts in Indonesia: A Structure Analysis. SOJOURN: Journal Of Social Issues In Southest Asia Vol. 30, No. 1 (2015), pp. 141-71.

[9] Salim, Arskal. 2006. Praktek Penyelesaian Formal dan Informal Masalah Pertanahan, Kewarisan dan Perwalian Pasca Tsunami di Banda Aceh dan Aceh Besar. Laporan Penelitian: International Development Law Organization. 